\title{
Brazilian Propolis: Correlation Between Chemical Composition and Antimicrobial Activity
}

\author{
Kelly Salomão ${ }^{1}$, Paulo Roberto S. Pereira ${ }^{1}$, Leila C. Campos ${ }^{2}$, Cintia M. Borba ${ }^{3}$, \\ Pedro H. Cabello ${ }^{4}$, Maria Cristina Marcucci ${ }^{5}$ and Solange L. de Castro ${ }^{1}$
}

${ }^{1}$ Departamento de Ultra-estrutura e Biologia Celular, ${ }^{2}$ Departamento de Bacteriologia, ${ }^{3}$ Departamento de Micologia, ${ }^{4}$ Departamento de Genética, Instituto Oswaldo Cruz, Fundação Oswaldo Cruz, Rio de Janeiro and ${ }^{5}$ Pós-graduação em Farmácia, Núcleo de Pós-graduação, Pesquisa e Extensão, Universidade Bandeirante de São Paulo, São Paulo, Brazil

The chemical composition of ethanol extracts from samples of Brazilian propolis (EEPs) determined by HPLC and their activity against Trypanosoma cruzi, Staphylococcus aureus, Streptococcus pneumoniae, Klebisiella pneumoniae, Candida albicans, Sporothrix schenckii and Paracoccidioides brasiliensis were determined. Based on the predominant botanical origin in the region of samples' collection, the 10 extracts were separated into three groups: A (B. dracunculifolia + Auraucaria spp), B (B. dracunculifolia) and C (Araucaria spp). Analysis by the multiple regression of all the extracts together showed a positive correlation, higher concentrations leading to higher biological effect, of $S$. aureus with $p$-coumaric acid (PCUM) and 3-(4-hydroxy-3-(oxo-butenyl)-phenylacrylic acid (DHCA1) and of trypomastigotes of $T$. cruzi with 3,5-diprenyl-4-hydroxycinnamic acid derivative 4 (DHCA4) and 2,2-dimethyl-6-carboxyethenyl-2H-1-benzopyran (DCBEN). When the same approach was employed for each group, due to the small number of observations, the statistical test gave unreliable results. However, an overall analysis revealed for group A an association of $S$. aureus with caffeic acid (CAF) and dicaffeoylquinic acid 3 (CAFQ3), of $S$. pneumoniae with CAFQ3 and monocaffeoylquinic acid 2 (CAFQ2) and of T. cruzi also with CAFQ3. For group B, a higher activity against $S$. pneumoniae was associated DCBEN and for $T$. cruzi with CAF. For group $\mathrm{C}$ no association was observed between the anitmicrobial effect and any component of the extracts. The present study reinforces the relevance of PCUM and derivatives, especially prenylated ones and also of caffeolyquinic acids, on the biological activity of Brazilian propolis.

Keywords: bactericidal activity - chemical composition - fungicidal activity-propolis-statistical analysis - Trypanosoma cruzi

\section{Introduction}

Propolis presents a complex composition depending basically on the plant sources accessible to the bees, possessing a variety of biological and pharmacologic

For reprints and all correspondence: Dr Solange L. de Castro, Departamento de Ultra-estrutura e Biologia Celular, Instituto Oswaldo Cruz, Fundação Oswaldo Cruz, Av. Brasil 4365, Manguinhos 21045900, Rio de Janeiro, RJ, Brazil. Te.: +55 21 25984330; Fax: +55 21 22604434; E-mail: solange@ioc.fiocruz.br activities, attracting the interest of an increasing number of researchers (1). Brazillian samples present striking differences in their chemical composition when compared with samples from temperate zones (2). Besides, differences are also found among tropical samples depending on the local flora at the site of collection (3). As examples we found the Brazilian green or Alecrim propolis, originated from Baccharis dracunculifolia (Asteraceae) (4-6), the Cuban red propolis from Clusia nemorosa (Clusiaceae) (7) and more recently the red propolis 
collected in the North region of Brazil (8). While the microbicidal activity of European propolis has been associated with the presence of flavonoids and derivatives of caffeic acid $(9,10)$, in the case of tropical samples, the main bioactive compounds are phenolic acids and prenylated derivatives (11).

Due to the increasing interest in the characteristics of Brazilian propolis, we undertook a study using samples collected in different regions, aiming to determine their effect against Trypanosoma cruzi and different species of bacteria and fungi. Trypanosoma cruzi is the etiologic agent of Chagas' disease, an important Public Health problem in Latin America, the treatment of which is still inadequate since the available drug benznidazole, a nitroderivative, causes severe side effects and its efficacy for chronic patients is questionable $(12,13)$. Streptococcus pneumoniae and Staphylococcus aureus were assayed since they can colonize the human nasopharynx and represent potential agents of several diseases $(14,15)$. Klebisiella pneumoniae was also included in the present work. Candida albicans, Sporothrix schenckii and Paracoccidioides brasiliensis, was selected due to their importance as etiologic agents of mycosis in Brazil (16,17).

\section{Materials and Methods}

\section{Propolis Extracts}

Eleven samples were collected in different regions in Brazil and $30 \mathrm{~g}$ of each resin were triturated and extracted with $100 \mathrm{ml}$ ethanol (Merck Darmstadt, Germany) for 20 days in the dark. Afterwards, the material was cooled for precipitation of waxes, which were removed by filtration and the extract was dried under reduced pressure at $60^{\circ} \mathrm{C}$. Their yield varied between 40 and $60 \%$. Stock solutions of the eleven extracts were prepared in dimethylsulfoxide (DMSO). Based on the predominant botanical origin in the region of samples collection they were separated as: group A (B. dracunculifolia plus Auraucaria spp, State of Paraná): EEP-01 to EEP-04; group B (B. dracunculifolia, State of Minas Gerais): EEP-05 to EEP-07 and, group C (Auraucaria spp, State of Paraná) EEP-08 to EEP-10. Another extract obtained from a red propolis collected in the State of Alagoas, EEP-11 (Schinus terebinthifolius, Diplotropis incexis and Manilkara huberi) was also included for the biological assays (8).

\section{HPLC-MS Analysis}

EEP-1 to EEP-10 were analyzed by HPLC (D-7000 Merck-Hitachi, Germany) equipped with a pump (model L-6200, Merck-Hitachi, Germany) and a diode array detector (L-3000, Merck-Hitachi, Germany) as previously described (18). Detection of the components was monitored at 280 and $340 \mathrm{~nm}$ and standard compounds were co-chromatographed with the extracts. ${ }^{1} \mathrm{H}-\mathrm{NMR}$ and ${ }^{13} \mathrm{C}-\mathrm{NMR}$ were recorded using a Varian Gemini 300 spectrophotometer and the mass spectra obtained in a Hewlett-Packard apparatus (model 5890 Series II Plus).

\section{Fungicidal Activity}

The agar cup method was used (19) to assay the effect of the EEPs against C. albicans (Ca IOC-3781), S. schenckii (Ss IOC-2832) and P. brasiliensis (Pb IOC-3698). Yeast cells of $C$. albicans were grown in Sabouraud medium (Difco Laboratories, Detroit, MI, USA) at $25^{\circ} \mathrm{C}$ and yeast-like cells of $S$. schenckii and $P$. brasiliensis were grown in brain heart infusion (BHI) (Difco) and peptoneyeast extract-glucose (PYG) (Difco) at $36^{\circ} \mathrm{C}$. The fungal cells were washed in phosphate-buffered saline (PBS, pH 7.2) counted in a hemocytometer and the concentration adjusted to $3.4 \times 10^{7}$ cells $\mathrm{ml}^{-1}$. A plate of a suitable sterile agar, poured to a depth of $4 \mathrm{~mm}$, was allowed to set and a single cup ( $15 \mathrm{~mm}$ diameter), cut from the centre of the plate. The cell suspensions $(50 \mu l)$ were streaked radially from the cup to the edge of the plate on the suitable agar medium surface for each fungus and the cup filled with $200 \mu \mathrm{l}$ of EEP $\left(2-16 \mathrm{mg} \mathrm{ml}^{-1}\right)$. The plates were incubated for 3 days at $25^{\circ} \mathrm{C}$ for C. albicans and for 6 days at $36^{\circ} \mathrm{C}$ for both $S$. schenckii and P. brasiliensis. The antifungal activity was measured as the diameter of the inhibitory zones. Controls were performed with DMSO, the solvent of the stock solutions of the extracts; no inhibition zone was observed. Diameters of less than $15 \mathrm{~mm}$ were considered as lack of activity.

\section{Bactericidal Activity}

The minimal inhibitory concentration (MIC) was determined by means of the broth microdilution method described by the National Committee for Clinical Laboratory Standards (20), followed by subculture. S. pneumoniae (ATCC 49619), S. aureus (ATCC 25923) and $K$. pneumoniae (ATCC 70603) were grown in Müeller-Hinton agar supplemented with 5\% sheep blood and incubated for $18 \mathrm{~h}$ at $37^{\circ} \mathrm{C}$. S. pneumoniae was incubated in a $5 \% \mathrm{CO}_{2}$ atmosphere. Bacterium inoculum was prepared in Müeller-Hinton Broth (Oxoid Ltd Basingstone, Hampshire, England), adjusted to 0.5

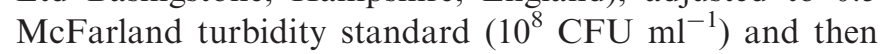
diluted 1:10. This suspension $(100 \mu \mathrm{l})$ was added to equal volume of the EEP, previously prepared by 2 -fold serial dilutions in 96-well plates. After $18 \mathrm{~h}$, subculture $(10 \mu \mathrm{l})$ from each well was made in the same conditions. MIC was considered the lowest concentration of the extract that yields negatives subcultures. The final concentration 
of DMSO in the assays did not interfere with proliferation of the bacteria.

\section{Trypanocidal Activity}

The Y strain of $T$. cruzi was used (21). Bloodstream trypomastigotes were obtained at the peak of parasitemia from infected albino mice, isolated by differential centrifugation and resuspended with Dulbecco's modified Eagle medium (DME) to a parasite concentration of $10 \times 10^{6}$ cells ml $^{-1}$ in the presence of $10 \%$ blood. This suspension $(100 \mu \mathrm{l})$ was added to the same volume of the EEP, previously prepared at twice the desired concentrations also in DME $\left(0.025-4 \mathrm{mg} \mathrm{ml}^{-1}\right)$ in 96-well plates and then incubated at $4{ }^{\circ} \mathrm{C}$. Trypomastigote concentration in the wells was $5 \times 10^{6}$ cells $\mathrm{ml}^{-1}$ containing $5 \%$ blood (22). Cell counts were performed after $24 \mathrm{~h}$ of incubation and the activity of the extracts was expressed as $\mathrm{IC}_{50}$ values, corresponding to the concentration that lysed $50 \%$ of the parasites. Experiments showed that in concentrations up to $0.2 \%$, DMSO had no deleterious effect on the parasites.

\section{Statistical Analysis}

The correlation of the trypanocidal $\left(\mathrm{IC}_{50}\right)$ or bactericidal (MIC) activity with the composition of each extract determined by HPLC, expressed in $\mathrm{mg} \mathrm{g}^{-1}$ of dried extract (Table 1), was performed by the method of analysis of multiple regressions using the software SPSS for Windows 8.0. Positive correlation means that higher concentrations of a specific component are associated with higher antimicrobial activity, while negative correlation, means that at lower concentrations a higher activity was achieved. It is important to note that, for a given extract, lower values of the parameters $\mathrm{IC}_{50}$ and $\mathrm{MIC}$ indicate a higher activity. The comparison between the $\mathrm{IC}_{50}$ values for $T$. cruzi was performed by ANOVA followed by the Student-Newman-Keuls test $(P<0.05)$.

\section{Results}

\section{Chemical Composition and Fungicidal Activity of the Extracts}

The chemical composition of each EEP quantified by HPLC is presented in Table 1. In order to better visualize the distribution of the components in groups $\mathrm{A}, \mathrm{B}$ and $\mathrm{C}$ based on the predominant vegetation the concentration of each component was included in each group expressed as mean \pm standard deviation (Fig. 1).

The effect of the extracts against C. albicans, S. schenckii and P. brasiliensis is presented in Fig. 2, being the latter species the most susceptible to propolis. No statistical correlation was performed; the values were expressed in diameter of inhibition zone expressed in $\mathrm{mm}$, for four different concentrations of each extract.

\section{Bactericidal Activity and Correlation With the Chemical Composition}

The MIC range for S. pneumoniae was $0.2-0.8 \mu \mathrm{g} \mathrm{m}{ }^{-1}$ and for $S$. aureus, $1.6-52.4 \mu \mathrm{g} \mathrm{ml}^{-1}$ (Fig. 3). All the extracts were inactive against $K$. pneumoniae. Analysis by the method of multiple regression of all the extracts together showed for $S$. aureus a positive correlation for $p$-coumaric acid (PCUM) $(P=0.0002)$ and 3-(4-hydroxy3-(oxo-butenyl)-phenylacrylic acid (DHCA1) $(P=0.006)$, meaning higher concentrations of each compound led to higher bactericidal effect and a negative one for 3methoxy-4-hydroxycinnamaldehyde $(\mathrm{G} 2)(P=0.001)$ and vanillin (VAN) $(P=0.026)$. While for $S$. pneumoniae, a negative correlation between the activity and the concentration of $\mathrm{G} 2(P=0.024)$ was observed. When the same approach was employed for each group, since the number of extracts was four, three and three, for groups $\mathrm{A}, \mathrm{B}$ and $\mathrm{C}$, respectively, the multiple regression analysis gave unreliable results. However, an overall analysis revealed for group A (B. dracunculifolia + Auraucaria spp) there was an association of concentrations of caffeic acid (CAF) and dicaffeoylquinic acid 3 (CAFQ3) with the activity against $S$. aureus, while for $S$. pneumoniae such association occurred and between CAFQ3 and monocaffeoylquinic acid 2 (CAFQ2). In group B (B. dracunculifolia) higher activity against $S$. pneumoniae was associated with 2,2-dimethyl-6-carboxyethenyl-2H-1benzopyran (DCBEN). For group C (Araucaria spp) no association was observed between the bactericidal effect and any component of the extracts.

\section{Trypanocidal Activity and Correlation With the Chemical Composition}

The activity of the extracts against bloodstream trypomastigote forms of T. cruzi is shown in Fig. 4. For each group the order of decreasing activity $(P<0.05)$ was: EEP-01> EEP-02, EEP-04>EEP-03, for group A; EEP-07>EEP-05, EEP-06, for group $B$ and EEP-9 > EEP-8 > EEP-10, for group C.

The statistical analysis of all the extracts together and the activity against $T$. cruzi showed a positive correlation with compounds 3,5-diprenyl-4-hydroxycinnamic acid derivative 4 (DHCA4) $(P=0.004)$ and DCBEN $(P=0.039)$ and a negative one for 2-[1-hydroxymethyl]vinyl-6-acetyl-5-hydroxycumarane (I) $(P=0.00008)$ and L2 $(P=0.006)$, a still non-identified compound. As stated earlier the multiple regression analysis could not be applied for each separated group of extracts, but there was a positive association of the trypanocidal activity with dicaffeoylquinic acid 3 (CAFQ3) for group A and 
Table 1. Chemical composition of ethanol extracts of Brazilian propolis samples ( $\mathrm{mg} \mathrm{g}^{-1}$ of dried extract)

\begin{tabular}{|c|c|c|c|c|c|c|c|c|c|c|}
\hline \multirow[b]{3}{*}{ Compounds } & \multicolumn{4}{|c|}{ Group A } & \multicolumn{3}{|c|}{ Group B } & \multicolumn{3}{|c|}{ Group C } \\
\hline & \multicolumn{4}{|c|}{ B. dracunculifolia + Auraucaria $\mathrm{spp}$} & \multicolumn{3}{|c|}{ B. dracunculifolia } & \multicolumn{3}{|c|}{ Auraucaria spp } \\
\hline & EEP-01 & EEP-02 & EEP-03 & EEP-04 & EEP-05 & EEP-06 & EEP-07 & EEP-08 & EEP-09 & EEP-10 \\
\hline $\begin{array}{l}\text { 2,2-Dimethyl-6-carboxyethenyl-2H- } \\
\text { 1-benzopyran (DCBEN) }\end{array}$ & 10.02 & 3.48 & 1.54 & 7.62 & 0.00 & 4.80 & 0.00 & 0.00 & 0.00 & 0.00 \\
\hline $\begin{array}{l}\text { 3,5-Diprenyl-4-hydroxycinnamic acid } \\
\text { (DHCA) }\end{array}$ & 20.80 & 5.03 & 2.38 & 26.70 & 36.13 & 38.37 & 33.04 & 0.00 & 0.00 & 0.00 \\
\hline $\begin{array}{l}\text { 3-(4-Hydroxy-3-(oxo-butenyl)-pheny- } \\
\text { lacrylic acid (DHCA1) }\end{array}$ & 3.10 & 1.67 & 0.00 & 0.95 & 1.35 & 1.30 & 0.83 & 0.00 & 0.00 & 0.00 \\
\hline $\begin{array}{l}\text { 3-Prenyl-4-(2-methoxypropionyloxy) } \\
\text { cinnamic acid (DHCA2) }\end{array}$ & 2.97 & 1.29 & 0.00 & 2.05 & 0.06 & 0.75 & 2.08 & 0.00 & 0.00 & 0.00 \\
\hline $\begin{array}{l}\text { 3,5-Diprenyl-4-hydroxycinnamic acid } \\
\text { derivative } 5 \text { (DHCA5) }\end{array}$ & 2.96 & 1.18 & 0.00 & 2.43 & 1.48 & 0.46 & 2.69 & 0.00 & 0.00 & 0.00 \\
\hline $\begin{array}{l}\text { 3,5-Diprenyl-4-hydroxycinnamic acid } \\
\text { derivative } 6 \text { (DHCA6) }\end{array}$ & 3.71 & 1.31 & 0.00 & 2.87 & 3.67 & 3.07 & 3.37 & 0.00 & 0.00 & 0.00 \\
\hline $\begin{array}{l}\text { 3,5-Diprenyl-4-hydroxycinnamic acid } \\
\text { derivative } 7 \text { (DHCA7) }\end{array}$ & 0.00 & 0.00 & 0.00 & 0.00 & 2.43 & 0.06 & 2.28 & 0.00 & 0.00 & 0.00 \\
\hline $\begin{array}{l}\text { 3,5-Diprenyl-4-hydroxycinnamic acid } \\
\text { derivative } 8 \text { (DHCA } 8 \text { ) }\end{array}$ & 0.00 & 0.00 & 0.00 & 0.00 & 3.09 & 7.20 & 3.73 & 0.00 & 0.00 & 0.00 \\
\hline $\begin{array}{l}\text { 3,5-Diprenyl-4-hydroxycinnamic acid } \\
\text { derivative } 9 \text { (DHCA9) }\end{array}$ & 0.00 & 0.00 & 0.00 & 0.00 & 9.25 & 3.75 & 2.64 & 0.00 & 0.00 & 0.00 \\
\hline $\begin{array}{l}\text { 3-Hydroxy-2,2-dimethyl-8-prenyl-2H- } \\
\text { 1-benzopyran-6-propenoic acid } \\
\text { (DHCA10) }\end{array}$ & 0.00 & 0.00 & 0.00 & 0.00 & 4.95 & 5.81 & 0.00 & 0.00 & 0.00 & 0.00 \\
\hline $\begin{array}{l}\text { 3,5-Diprenyl-4-hydroxycinnamic acid } \\
\text { derivative } 14 \text { (DHCA14) }\end{array}$ & 0.00 & 0.00 & 0.00 & 0.00 & 3.47 & 0.00 & 0.00 & 0.00 & 0.00 & 0.00 \\
\hline p-Coumaric acid (PCUM) & 19.07 & 9.56 & 0.79 & 15.42 & 33.48 & 32.47 & 18.81 & 0.00 & 0.00 & 0.00 \\
\hline Caffeic acid (CAF) & 2.39 & 1.54 & 0.00 & 0.00 & 1.35 & 1.55 & 2.94 & 0.00 & 0.00 & 0.00 \\
\hline Cinnamic acid derivative 1 (CIN1) & 1.58 & 1.01 & 0.00 & 7.07 & 0.00 & 0.00 & 0.00 & 0.00 & 5.28 & 0.00 \\
\hline $\begin{array}{l}\text { 3-Prenyl-4-dihydrocinnamoyl-oxy- } \\
\text { cinnamic acid (CIN2) }\end{array}$ & 0.00 & 0.00 & 0.00 & 1.42 & 0.00 & 0.00 & 0.00 & 0.00 & 0.00 & 0.00 \\
\hline Benzoic acid (BENZ) & 0.00 & 0.00 & 6.53 & 0.00 & 0.00 & 0.00 & 0.00 & 0.00 & 24.74 & 0.00 \\
\hline Monocaffeoylquinic acid 1 (CAFQ1) & 7.35 & 6.35 & 0.00 & 6.05 & 9.79 & 13.59 & 4.31 & 0.00 & 0.00 & 0.00 \\
\hline Monocaffeoylquinic acid 2 (CAFQ2) & 1.57 & 1.49 & 0.00 & 0.00 & 4.06 & 0.00 & 0.00 & 0.00 & 0.00 & 0.00 \\
\hline Dicaffeoylquinic acid 1 (CAFQ3) & 2.79 & 0.00 & 0.00 & 0.00 & 0.00 & 0.00 & 0.00 & 0.00 & 0.00 & 0.00 \\
\hline Dicaffeoylquinic acid 2 (CAFQ4) & 0.61 & 0.50 & 0.13 & 0.37 & 0.99 & 1.85 & 0.63 & 0.00 & 0.00 & 0.00 \\
\hline Pinobanksin (PK) & 0.00 & 0.00 & 0.00 & 0.00 & 45.61 & 34.92 & 26.00 & 0.00 & 0.00 & 0.00 \\
\hline Kaempferol (KAEMP) & 0.00 & 0.00 & 0.00 & 3.91 & 0.00 & 0.00 & 0.00 & 0.00 & 1.60 & 0.00 \\
\hline Kaempferide (KAEMP1) & 20.80 & 0.00 & 0.00 & 11.76 & 37.05 & 34.08 & 33.04 & 0.00 & 0.00 & 0.00 \\
\hline Crysine (CRYS) & 0.00 & 0.00 & 0.00 & 0.00 & 0.00 & 0.00 & 0.00 & 0.00 & 6.24 & 0.00 \\
\hline
\end{tabular}


Table 1. Continued

\begin{tabular}{|c|c|c|c|c|c|c|c|c|c|c|}
\hline \multirow[b]{3}{*}{ Compounds } & \multicolumn{4}{|c|}{ Group A } & \multicolumn{3}{|c|}{ Group B } & \multicolumn{3}{|c|}{ Group C } \\
\hline & \multicolumn{4}{|c|}{ B. dracunculifolia + Auraucaria $\mathrm{spp}$} & \multicolumn{3}{|c|}{ B. dracunculifolia } & \multicolumn{3}{|c|}{ Auraucaria $\mathrm{spp}$} \\
\hline & EEP-01 & EEP-02 & EEP-03 & EEP-04 & EEP-05 & EEP-06 & EEP-07 & EEP-08 & EEP-09 & EEP-10 \\
\hline $\begin{array}{l}\text { 3-Methoxy-4-hydroxycinnamaldehyde } \\
\text { (G2) }\end{array}$ & 0.00 & 0.00 & 1.01 & 5.09 & 0.00 & 0.00 & 0.00 & 0.72 & 0.32 & 2.95 \\
\hline Galangin (GAL) & 0.00 & 0.00 & 0.00 & 0.00 & 0.00 & 0.00 & 0.00 & 0.00 & 11.50 & 0.00 \\
\hline Compound E (E) & 48.52 & 15.48 & 0.00 & 43.46 & 78.00 & 77.81 & 56.22 & 0.00 & 0.00 & 0.00 \\
\hline Compound $\mathrm{H}(\mathrm{H})$ & 0.00 & 0.00 & 20.60 & 0.00 & 0.00 & 0.00 & 0.00 & 11.61 & 97.38 & 17.68 \\
\hline Compound L2 (L2) & 0.00 & 0.00 & 0.00 & 0.00 & 0.00 & 0.00 & 0.00 & 3.67 & 0.00 & 3.61 \\
\hline
\end{tabular}

with CAF for group B. For group C (Araucaria spp) no association was observed between the effect against trypomastigote forms and any component of the extracts.

\section{Discussion}

Propolis samples from tropical zones, such as Brazil with its vast biodiversity, have become a subject of increasing scientific and economic attention. From Brazilian propolis, several bioactive derivatives of hydroxycinnamic, caffeoylquinic and diterpenic acids besides benzofuranes and benzopyranes have already been characterized $(18,23-25)$.

As typical of Brazilian propolis (2), most of the compounds present in the EEPs were phenolics, being present in high content hydroxycinnamic acids, such as PCUM and CAF and their prenylated derivatives. For group A (B. dracunculifolia + Araucaria spp), the extracts are typified as BRP(PR) based on the main bioactive components DHCA, DCBEN, 3-prenyl-4-hydroxycinnamic acid (PHCA) and 2,2-dimethyl-8-prenyl-2H-1benzopyran-6-propenoic acid (DPB) (26). For group B (Araucaria spp), they are typified as BRP-1 (26) with the main components being DHCA, PHCA, DPB, PCUM and $\mathrm{CAF}$, containing also caffeoylquinic acid derivatives. The extracts originated from Auraucaria spp (group C) are characterized as BRG, rich in coniferaldehyde compounds (VAN, G2 and I) (26). In relation to flavonoids, PK $\left(26.0-45.6 \mathrm{mg} \mathrm{g}^{-1}\right.$ of dried extract) and kaempferide (KAEMP1) (33.0-37.1 $\mathrm{mg} \mathrm{g}^{-1}$ ) were detected only in the three extracts of group B. KAEMP1 was also detected in two out of the four EEPs of group A.

From EEP-11, the most active extract, a red propolis collected in the State of Alagoas, has been already isolated: simple phenolics, triterepenoids, isoflavonoids, prenylated benzophenones and naphtoquinone epoxide (8).
Red colored propolis has been previously reported as typical in Cuba (7) and in Venezuela (11).

The fungicidal activity of Brazilian propolis has already been reported $(27,28)$. All the extracts assayed presented similar activities considering a given fungus species and an overall analysis shows that $P$. brasiliensis was more susceptible to the extracts than $C$. albicans and $S$. schenckii.

As observed with propolis from temperate regions, Brazilian samples also present a higher activity against Gram-positive bacteria than Gram-negative ones $(29,30)$, as observed in the present work using $K$. pneumoniae. The relationship of propolis origin, chemical composition and activity against $S$. aureus, as observed in the present study, was in accordance with the reports of other investigators $(31,32)$. The statistical analysis of all the extracts together revealed that higher concentrations of PCUM and DHCA1 are correlated with higher activity against $S$. aureus.

The $\mathrm{IC}_{50}$ for the activity against $T$. cruzi was in the range of $200-2000 \mu \mathrm{g} \mathrm{ml}^{-1}$, while for the standard drug, crystal violet, in the same experimental conditions, the value was $187.0 \pm 21.0 \mu \mathrm{g} \mathrm{ml}^{-1}$ (33). Statistical analysis of all the extracts showed that higher levels of DHCA4 and DCBEN were associated with higher trypanocidal effect.

The separation of the extracts in groups A, B and C, decreasing the number of observations in each group, prevented the application of multiple regression analysis. However, for $S$. aureus, S. pneumoniae and T. cruzi, we found, always a positive association of the biological activity with derivatives of PCUM and of caffeolyquinic acids, which correspond to caffeic acids esterified with sugar residues.

For both $S$. aureus and $T$. cruzi higher levels of 4-hydroxy cinnamic acid and derivatives were associated with a stronger biological activity, while no correlation was found between such activities and the content of flavonoids. DHCA and DCBEN, previously 
A

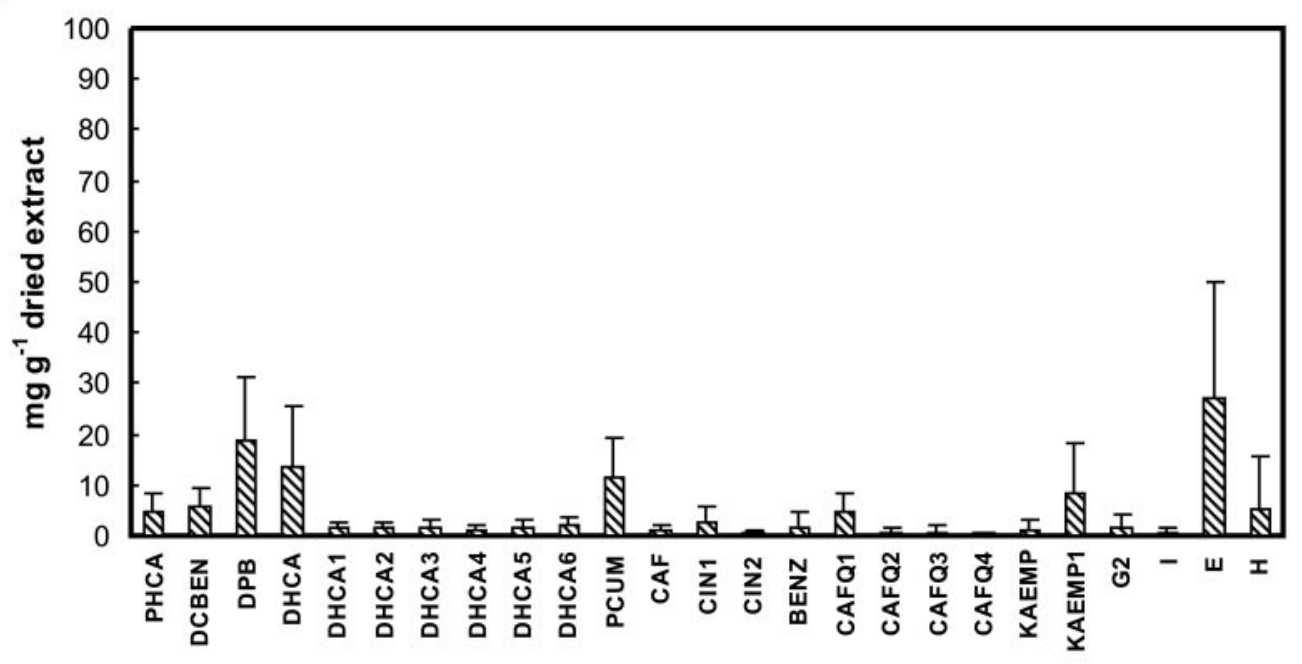

B

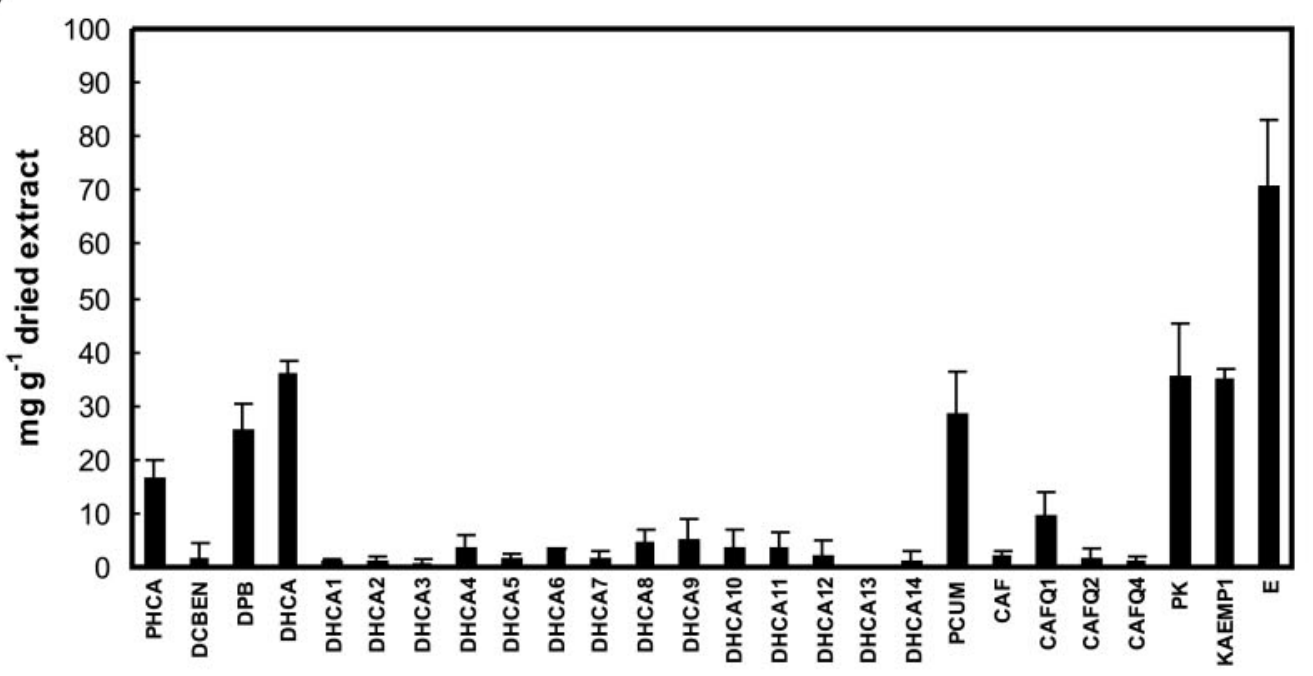

C

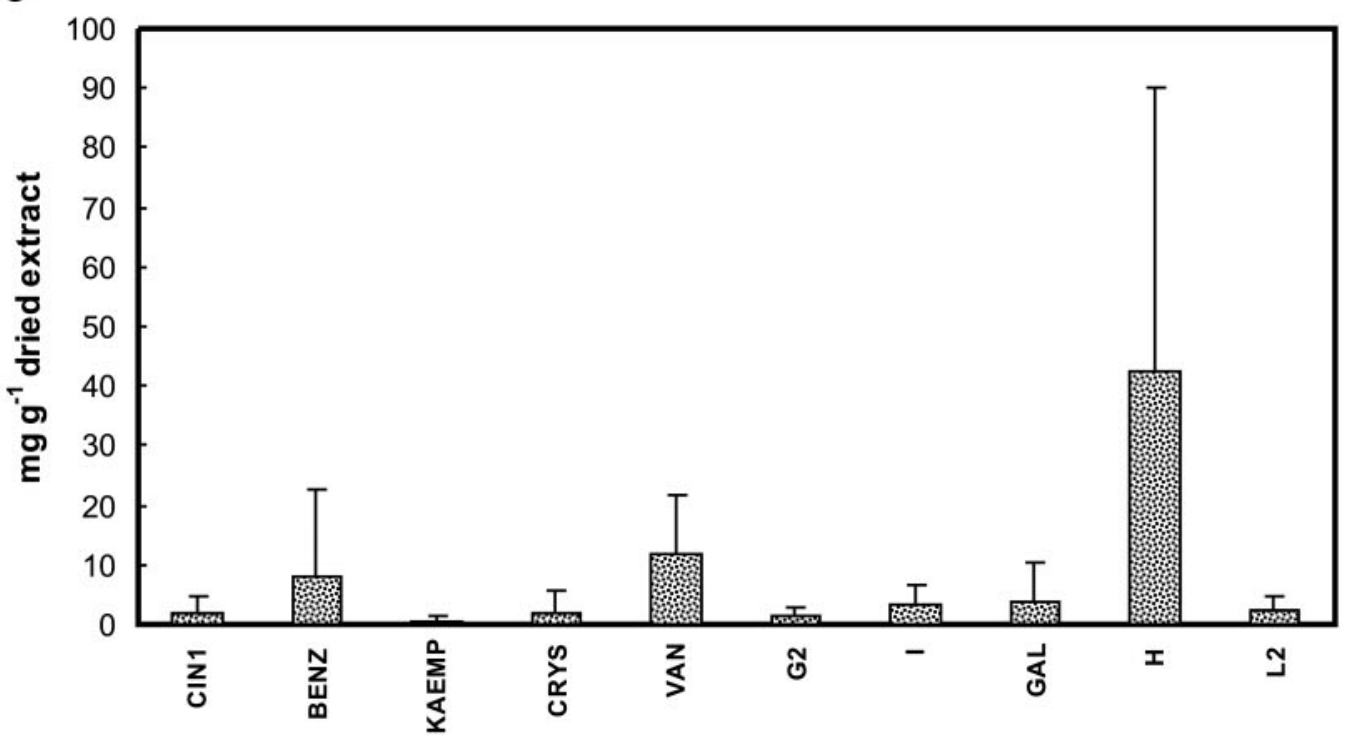

Figure 1. Concentration expressed in $\mathrm{mg} \mathrm{g}^{-1}$ dried extract (mean \pm standard deviation) of individual components of the ethanol extracts of Brazilian propolis samples separated by botanical origin: (A) group A; (B) group B; (C) group C. 
a

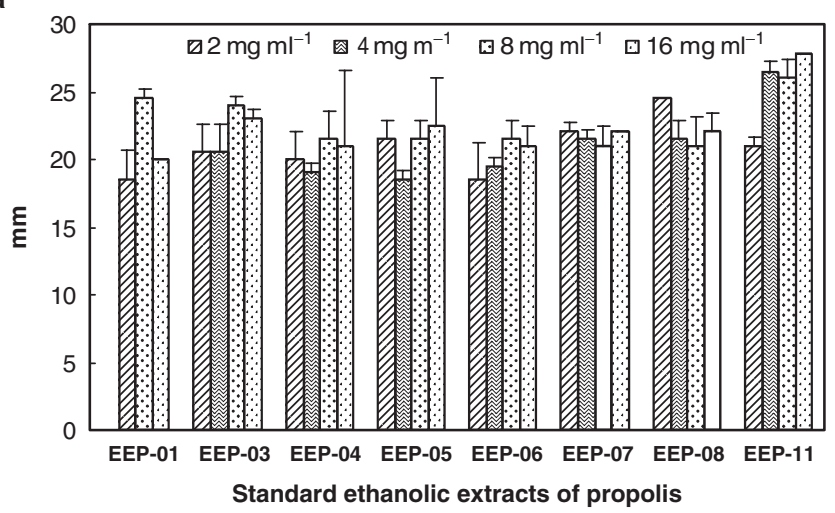

b
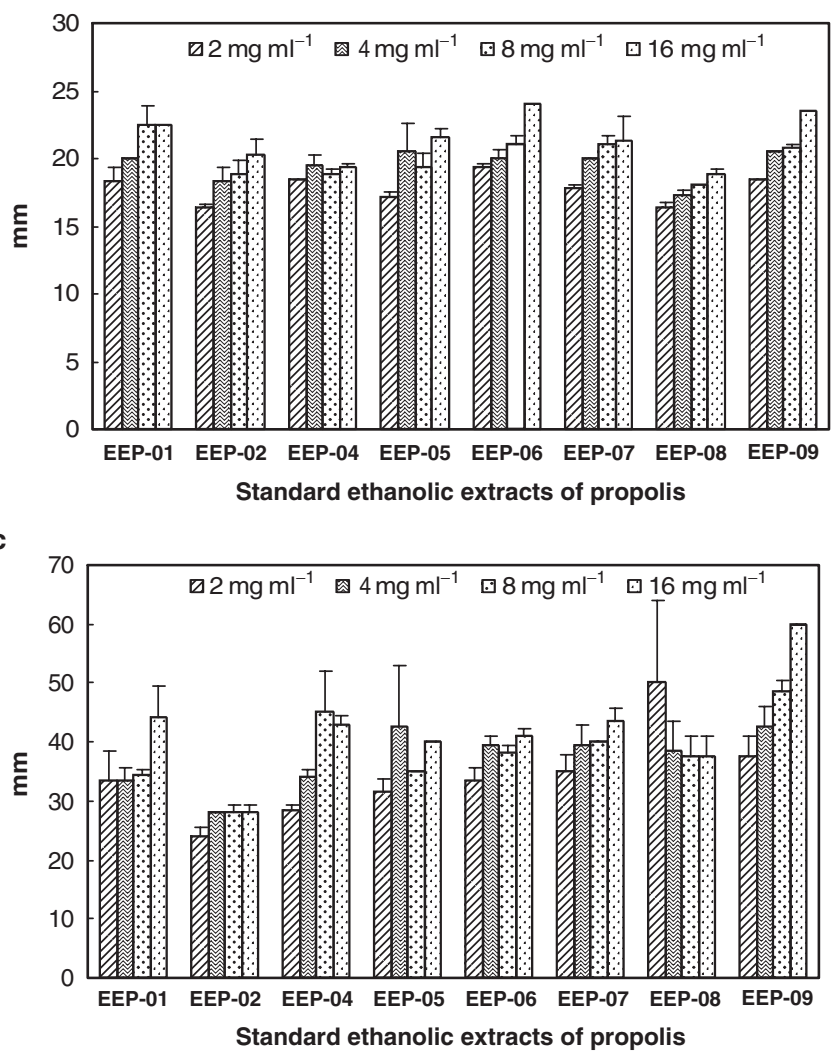

Figure 2. Fungicidal activity of Brazilian propolis extracts (2, 4, 8 and $16 \mathrm{mg} \mathrm{m}^{-1}$ ) expressed as diameter of inhibition in mm: (a) Candida albicans; (b) Sporothrix schenckii; (c) Paracoccidiodes brasiliensis.

characterized both in Brazilian propolis and in its main plant source, B. dracunculifolia, were active against $T$. cruzi and $S$. aureus $(18,34)$ and are useful markers to typify different samples (26).

The association of the chemical composition of propolis from different geographic regions with biological activities lead to the identification of active principles, a fundamental tool to achieve standardization of this bee product. The present study reinforces the relevance of PCUM and derivatives, especially prenylated ones and also of caffeolyquinic acids, on the biological activity of Brazilian propolis.
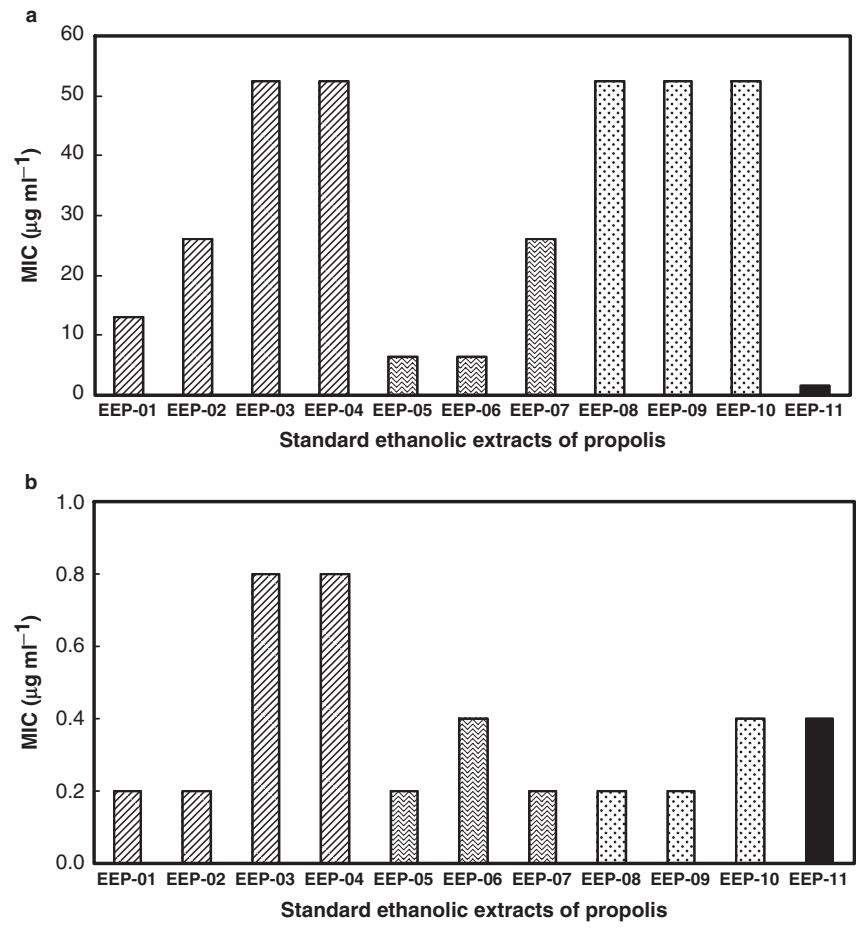

Figure 3. Bactericidal activity of Brazilian propolis extracts expressed as MIC values in $\mu \mathrm{g} \mathrm{ml} \mathrm{m}^{-1}$ : (a) Streptococcus pneumoniae; (b) Staphylococcus aureus.

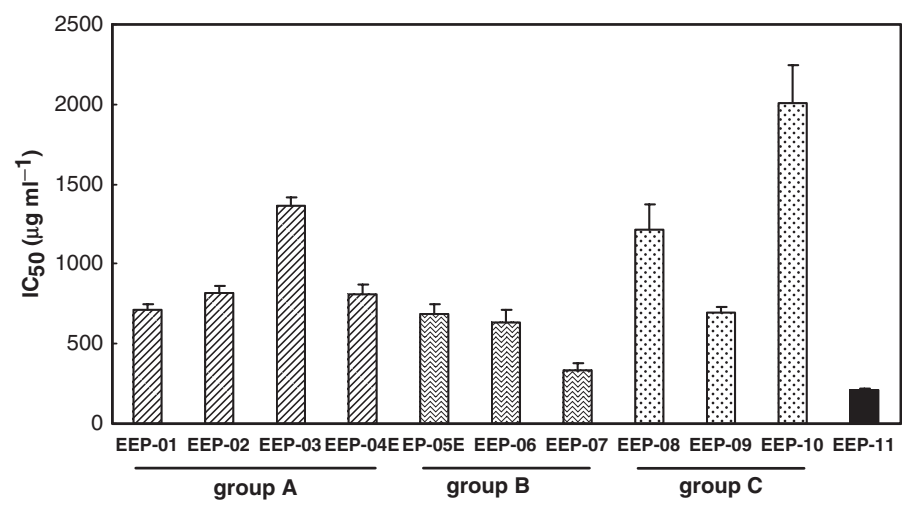

Figure 4. Effect of the Brazilian propolis extracts against bloodstream trypomastigotes of Trypanosoma cruzi after 1 day of treatment at $4{ }^{\circ} \mathrm{C}$. The bars represent the standard deviation of at least three independent experiments. The activity of EEP-01 was higher than that of EEP-02, EEP-04 and EEP-03 $(P<0.05)$; the activity of EEP-07 was higher than that of EEP-052, EEP-06 $(P<0.05)$; the activity of EEP-9 was higher than that of EEP-8, which has higher than that of EEP-10 $(P<0.05)$.

\section{Acknowledgements}

This work was supported by grants from the FAPESP (00/10031-0), CNPq and Papes/FIOCRUZ. Dr Alexandra C.H.F.Sawaya is also acknowledged for discussions about classification of propolis using Massfingerprint. 


\section{References}

1. De Castro SL. Propolis: biological and pharmacological activities. Therapeutic uses of this bee-product. Ann Rev Biomed Sci 2001;3:49-83.

2. Marcucci MC, Bankova VS. Chemical composition, plant origin and biological activity of Brazilian propolis. Curr Top Phytochem 1999;2:115-23.

3. Park YK, Alencar SM, Aguiar CL. Botanical origin and chemical composition of Brazilian propolis. J Agric Food Chem 2002;50:2502-6.

4. Park YK, Paredes-Guzman JF, Aguiar CL, Alencar SM, Fujiwara FY. Chemical constituents in Baccharis dracunculifolia as the main botanical origin of southeastern Brazilian propolis. J Agric Food Chem 2004;52:1100-3.

5. Salatino A, Teixeira EW, Negri G, Message D. Origin and chemical variation of Brazilian propolis. Evid Based Complement Alternat Med 2005;2:33-8.

6. Teixeira EW, Negri G, Meira RM, Message D, Salatino A. Plant origin of green propolis: bee behavior, plant anatomy and chemistry. Evid Based Complement Alternat Med 2005;2:85-92.

7. Hernandez IM, Fernandez MC, Cuesta-Rubio O, Piccinelli AL, Rastrelli L. Polyprenylated benzophenone derivatives from Cuban propolis. J Nat Prod 2005;68:931-4.

8. Trusheva B, Popova M, Bankova VS, Simova S, Marcucci MC, Miorin PL, et al. Bioactive constituents of Brazilian red propolis. Evid Based Complement Alternat Med 2006;3:249-54.

9. Hegazi AG, Abd-El-Hady FK, Abd-Allah FA. Chemical composition and antimicrobial activity of European propolis. Z Naturforsch 2000;55C:70-5.

10. Prytzyk E, Dantas AP, Salomão K, Pereira AS, Bankova VS, De Castro SL, et al. Flavonoids and trypanocidal activity of Bulgarian propolis. J Ethnopharmacol 2003;88:189-93.

11. Trusheva B, Popova M, Naydenski H, Tsvetkova I, Rodriguez JG, Bankova VS. New polyisoprenylated benzophenones from Venezuelan propolis. Fitoterapia 2004;75:683-9.

12. WHO. Chagas disease Thirteenth Programme Report UNDP/WB/ TDR. Geneve 1997;00:112-23.

13. Coura JR, De Castro SL. A critical review on Chagas disease chemotherapy. Mem Inst Oswaldo Cruz 2002;91:3.

14. Jacobs MR. Streptococcus pneumoniae: epidemiology and patterns of resistance. Am J Med 2004;117:3S-15S.

15. Todd JK. Staphylococcal infections. Ped Rev 2005;26:444-50.

16. Barros MBL, Schubach TMP, Galhardo MCG, Schubach AO, Monteiro PCF, Reis RS, et al. Sporotrichosis: An emergent zoonosis in Rio de Janeiro. Mem Inst Oswaldo Cruz 2001;96:777-9.

17. Borges-Walmsley MI, Chen D, Shu X, Walmsley AR. The pathobiology of Paracoccidioides brasiliensis. Trends Microbiol 2002;10:80-7.

18. Marcucci MC, Ferreres F, Garcia-Viguera C, Bankova VS, De Castro SL, Dantas AP, et al. Phenolic compounds from Brazilian propolis with pharmacological activities. J Ethnopharmacol 2001;74:105-12.
19. Spooner FD, Sykes G. Laboratory assessment of antibacterial activity. In: Norris E, Ribbons DN (eds). Methods in Microbiology. London: Academic Press, 1972, 45-9.

20. NCCLS. Methods for dilution antimicrobial susceptibility tests for bacteria that grow aerobically; approved standard. Technical Report M07-A6, 6th edn. PA: Wayne, 2003.

21. Silva LHP, Nussenszweig V. Sobre uma cepa de Trypanosoma cruzi virulenta para o camundongo branco. Folia Clin Biol 1953;20:191-207.

22. Cunha IBS, Salomão K, Shimizu M, Bankova VS, Custodio AR, Castro SL, et al. Antitrypanosomal activity of Brazilian propolis from Apis mellifera. Chem Pharm Bull 2004;52:602-4.

23. Bankova VS, Marcucci MC, Simova S, Nikolova N, Kujumgiev A, Popov S. Antibacterial diterpenic acids from Brazilian propolis. Z Naturforsch 1996;51C:277-80.

24. Basnet P, Matsushige K, Hase K, Kadota S, Namba T. Potent antihepatotoxic activity of dicaffeoyl quinic acids from propolis. Biol Pharm Bull 1996;19:655-7.

25. Hirota M, Matsuno T, Fujiwara T, Sugiyama H, Mineshita S. Enhanced cytotoxicity in a Z-photoisomer of a benzopyran derivative of propolis. $J$ Nat Prod 2000;63:366-70.

26. Marcucci MC. Process to typing natural products. Patente requerida Instituto Nacional de Propriedade Intelectual, INPI $\mathrm{n}^{\circ}$. PI 0105471-6, December 22, 2000.

27. Sforcin JM, Fernandes A Jr, Lopes CAM, Funari SRC, Bankova VS. Seasonal effect of Brazilian propolis on Candida albicans and Candida tropicalis. J Venom Anim Toxins 2001;7:139-44

28. Salomão K, Dantas AP, Borba CM, Campos LC, Machado DG, Aquino Neto FR, et al. Chemical composition and microbicidal activity of extracts from Brazilian and Bulgarian propolis. Lett Appl Microbiol 2004;38:87-92.

29. Sforcin JM, Fernandes A Jr, Lopes CAM, Bankova VS, Funari SRC. Seasonal effect on Brazilian propolis antibacterial activity. J Ethnopharmacol 2000;73:243-9.

30. Pinto MS, Faria JE, Message D, Cassini STA, Pereira CS, Gioso MM. Efeito de extratos de própolis verde sobre bactérias patogênicas isoladas do leite de vacas com mastite. Braz J Vet Res Anim Sci 2001;38:278-83.

31. Nieva Moreno MI, Isla MI, Cudmani NG, Vattuone MA, Sampietro AR. Screening of antibacterial activity of Amaicha del Valle (Tucuman, Argentina) propolis. $J$ Ethnopharmacol 1999; 15:97-102.

32. Lu LC, Chen YW, Chou CC. Antibacterial activity of propolis against Staphylococcus aureus. Int J Food Microbiol 2005; 15:213-20.

33. De Castro SL, Pinto MCFR, Pinto AV. Screening of natural and synthetic drugs against Trypanosoma cruzi: I- Establishing a structure/activity relationship. Microbios 1994;78:83-90.

34. Aga H, Shibuya T, Sugimoto T, Kurimoto M, Nakajima SH. Isolation and identification of antimicrobial compounds in Brazilian propolis. Bios Biotech Biochem 1994;58:945-6.

Received October 24, 2006; accepted April 12, 2007 


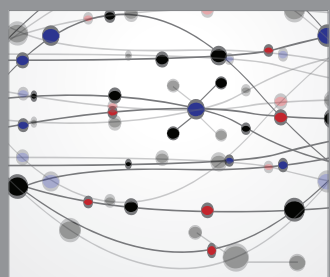

The Scientific World Journal
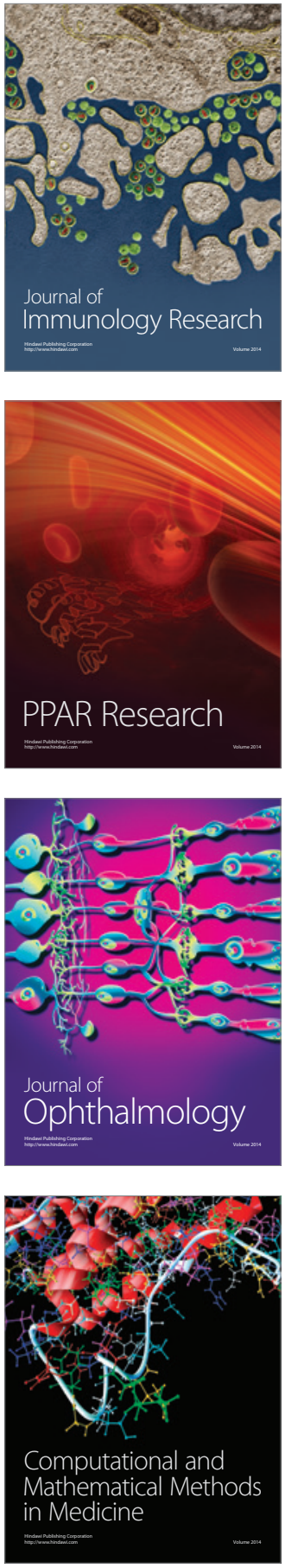

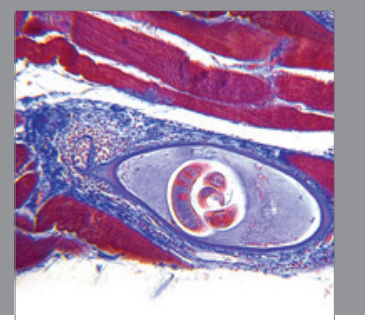

Gastroenterology

Research and Practice
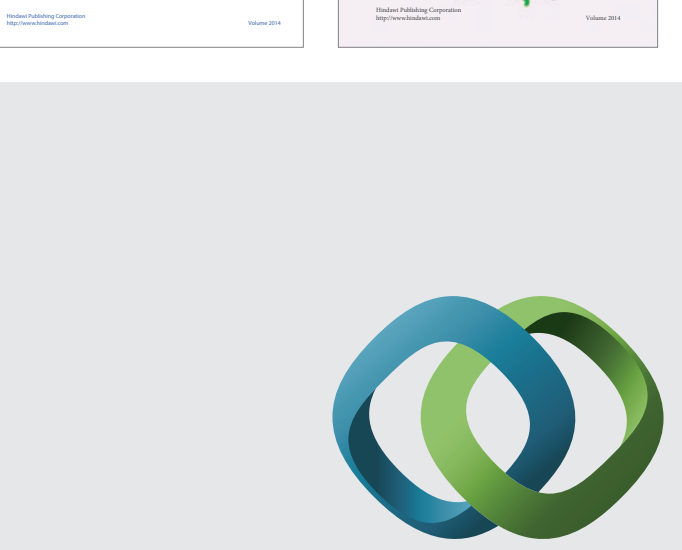

\section{Hindawi}

Submit your manuscripts at

http://www.hindawi.com
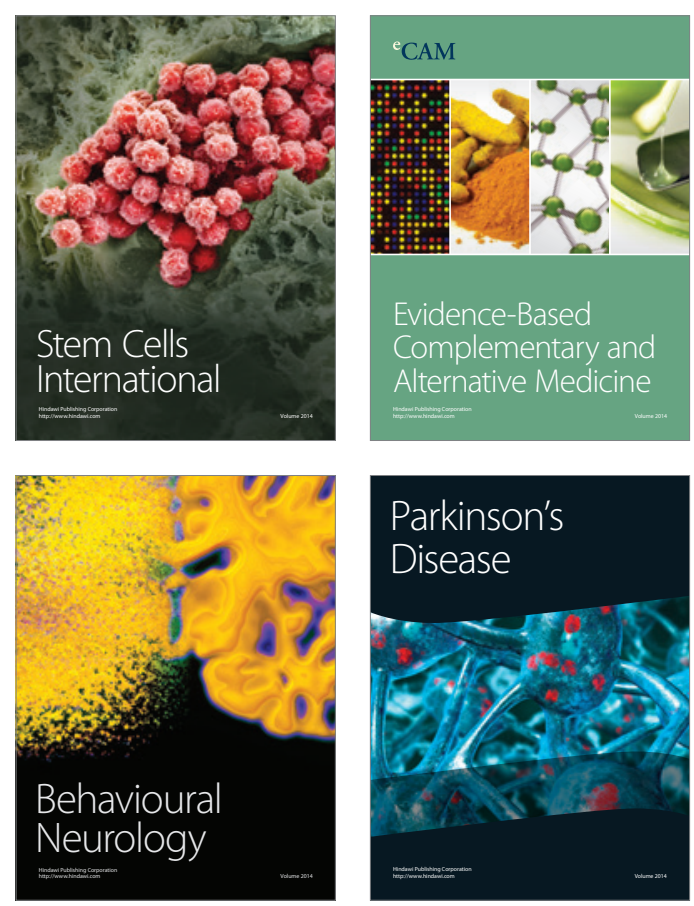

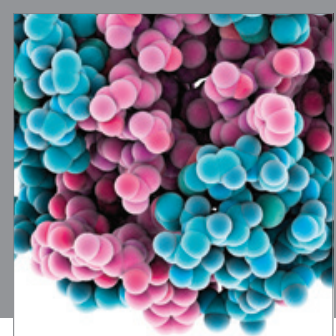

Journal of
Diabetes Research

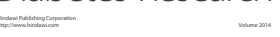

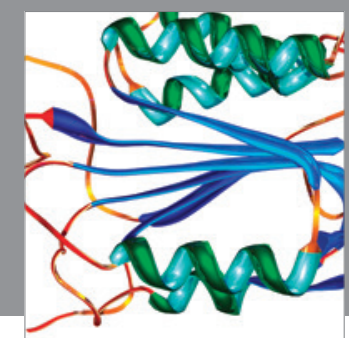

Disease Markers
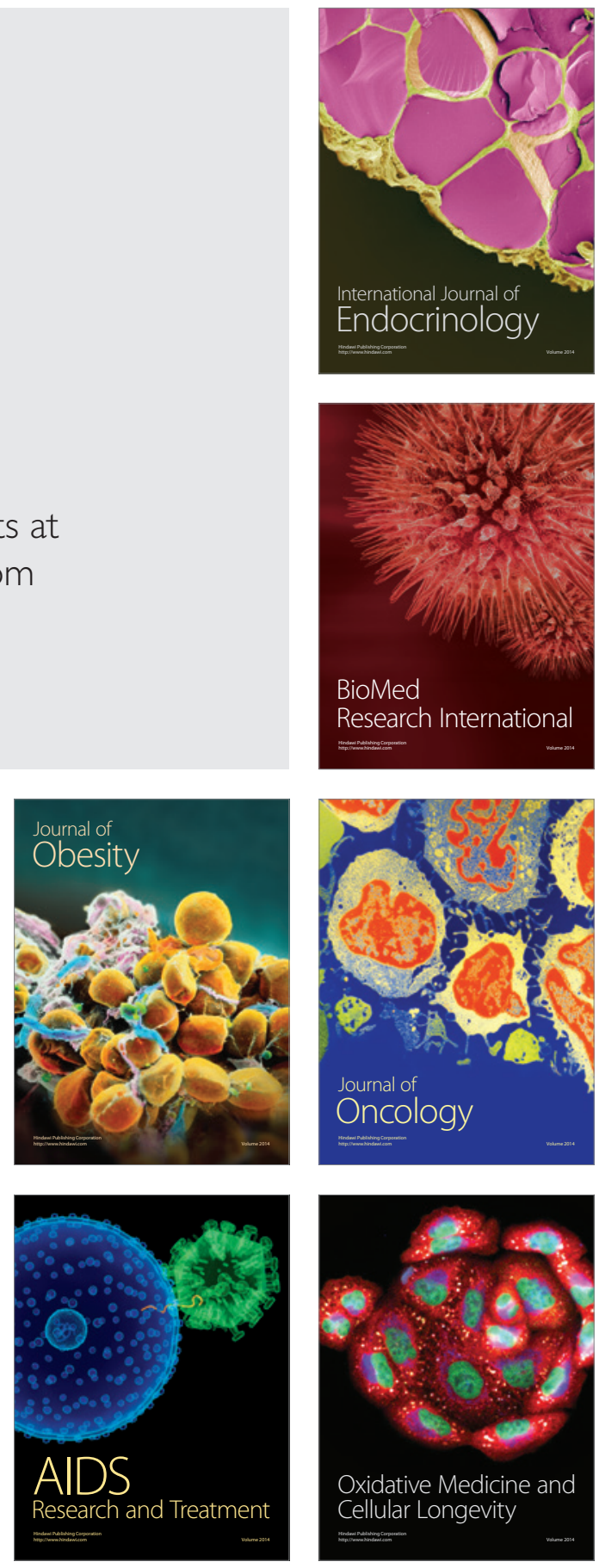